\title{
Effects of Range Improvement on Roosevelt Elk Winter Nutrition
}

\author{
IHOR M. MERESZCZAK, WILLIAM C. KRUEGER, AND MARTIN VAVRA
}

\section{Abstract}

Three pasture types dominate the Beneke Creek Wildlife Management Area on this Roosevelt elk winter range in northwestern Oregon. In winter, elk showed a strong preference for perennial ryegrass pastures that were hayed the previous summer and fall fertilized over bentgrass pastures also hayed and fertilized or unmanaged bentgrass pastures. These perennial ryegrass pastures provided forage that met minimal requirements for digestible protein and digestible energy all winter while both bentgrass pasture types were deficient in these nutrients through winter. Improvement of bentgrass pastures by conversion to ryegrass should result in higher rates of elk reproduction and better survival of offspring.

In 1973 the Oregon Department of Fish and Wildlife purchased bottomland pastures in the Coast Range Mountains of northwestern Oregon to provide wintering areas for Roosevelt elk (Cervus canadensis roosevelti). The increasing demands of the public for more elk to view and harvest, combined with the Oregon Department of Fish and Wildlife's desire to maximize production of elk from these pastures, has prompted them to undertake an intensive vegetation management program on the purchased lands. The intensive management on these areas has resulted in an increase in wintering elk populations. However, no data were available on the quality of winter forage provided by the intensively managed pastures as compared to undeveloped pastures.

Trainer (1971) stated that under the stress of lactation, most Roosevelt elk cows in western Oregon were unable to maintain adequate energy reserves. During the breeding season, little evidence of ovulation was found for cows in lactation. This was related to their poor condition. During the year in which the cow was barren and dry, energy reserves were restored to a level where ovulation again occurred. Therefore, many Roosevelt elk cows produce a calf every other year, rather than yearly (Trainer 1971). Trainer further suggested that the quality of elk forage was at least in part responsible for this situation. Harper (1962) stated that overpopulation and/or poor forage quality could have contributed to the low nutritional status of Roosevelt elk on Boyes Prairie, California. Schwartz and Mitchell (1945) blamed poor forage quality as the cause of most malnutrition deaths of Roosevelt elk on the Olympic Peninsula, Washington, since most animals examined had their paunch full of ". . . coarse and unpalatable. .." forage. Poor winter nutrition appears to be a problem for Roosevelt elk throughout their range.

Since forage quality has been accepted as a key criterion by which vegetation management practices can be judged, the objectives of this research were to determine the effects of bottomland pasture development on the nutritive values of forage for wintering Roosevelt elk and on elk preference among pastures.

Authors are graduate student and associate professors, Rangeland Resources Program, Oregon State University, respectively. Dr. Krueger is Head, Dept. of Range Science, Colorado State University, Fort Collins. Mr. Mereszczak is currently a member of the Range Staff on the Medicine Bow National Forest, Encampment, Wyoming. Dr. Vavra is at the Eastern Oregon Agricultural Research Center, Union, Oregon. The authors express their appreciation to Mr. Bert Cleary of the Oregon Department of Fish and Wild life for his many helpful suggestions and to the Oregon Department of Fish and Wildlife for logistic support throughout the study.

Manuscript received September 10, 1979.

\section{Study Area}

This research was conducted on the Beneke Creek Wildlife Management Area (W.M.A.), Clatsop County, Oregon. The W.M.A. encompasses $276 \mathrm{ha}$, most of which is stream bottom and alluvial terraces of unconsolidated stream sediments (Beaulieu 1973). Approximately 48 ha are slopes of the Coast Range Mountains. The average annual precipitation was $150 \mathrm{~cm}, 66 \%$ of which fell from November through March. The average daily maximum and minimum temperatures were $16^{\circ}$ and $3^{\circ} \mathrm{C}$, respectively (NOAA 1968-1978).

Following acquisition of the property, the Oregon Department of Fish and Wildlife began to plow and reseed pastures to species that were considered more productive and more palatable during the winter. Fall fertilization and hay removal wcre implemented on most pastures that were level enough to do so. As a result of this habitat development, three types of perennial pastures were present on the area.

Untreated Colonial Bentgrass (Agrostis tenuis) (Bentgrass-U): These pastures were cleared of trees more than 50 years ago, possibly broadcast seeded in spots and grazed by livestock, but never tilled. They were neither hayed nor fertilized and were heavily dominated by colonial bentgrass.

Treated Colonial Bentgrass (Bentgrass-T): These pastures were tilled in the past. They most likely were once grain fields and later used for pastures, but have not been tilled for at least 20 years. Since the purchase of the area, these pastures have been hayed and fall fertilized with 10-20-10 fertilizer at a rate of $390 \mathrm{~kg} / \mathrm{ha}$ each year. These pastures were also heavily dominated by colonial bentgrass.

Treated Perennial Ryegrass (Lolium perenne) (Ryegrass-T): These pastures were plowed, limed, planted with a cover crop of cereal rye through the first winter, then plowed again the next spring and seeded to a pasture mixture of: perennial ryegrass, annual ryegrass (Lolium multiflorum), orchardgrass (Dactylis glomerata), tall fescue (Festuca arundinacea), white clover (Trifolium repens) and subterranean clover (Trifolium subterraneum). They were hayed and fall fertilized yearly with 10-20-10 fertilizer at a rate of $390 \mathrm{~kg} / \mathrm{ha}$. They were heavily dominated by perennial ryegrass. Development of these pastures has been the goal of the elk habitat program on the Beneke Creek W.M.A.

The experimental pastures were comprised of eight plant communities. Similarities among plant communities were specific to each of the pasture types (Table 1).

The timbered areas were dominated by red alder (Alnus rubra) and Douglas-fir (Pseudotsuga menziesii) on the hillsides and sitka spruce (Picea sitchensis), western red cedar (Thuja plicata) and bigleaf maple (Acer macrophyllum) in the bottoms.

\section{Methods}

Sampling was conducted during December, January, and February of the 1976-1977 and 1977-1978 winters. Each winter was partitioned into three 30-day (monthly) sampling periods. Comparisons were made between the Bentgrass- $U$, Bentgrass- $T$, and Ryegrass- $T$ pasture types. 
Table 1. Dominant plant communities and associated pasture types on the Beneke Creek Wildlife Management Area.

Plant community

Pasture types

1. Wild blackberry/Colonial bentgrass/ Buckhorn plantain

2. Wild blackberry/Colonial bentgrass/ Birdsfoot trefoil

3. Evergreen blackberry/Colonial bentgrass/ Birdsfoot trefoil

4. Colonial bentgrass/White clover

5. Colonial bentgrass/Sheep sorrel

6. Colonial bentgrass/Buckhorn plantain/ Birdsfoot trefoil

7. Perennial ryegrass/White clover

8. Cereal rye

9. Woodland

Total standing biomass of herbage and herbage removal were estimated monthly from weighed, oven-dried $\left(50^{\circ} \pm 5^{\circ} \mathrm{C}\right)$ samples acquired by clipping caged and uncaged paired, $0.22-\mathrm{m}^{2}$ circular plots. Three pastures for each of the pasture types being compared were selected to represent and replicate the appropriate pasture types. Fifteen subsample estimates, apportioned according to relative area of each plant community in each replication, for each of the above parameters were averaged to provide a value for each of the three replications in each of the three pastures types.

The 15 caged samples of herbage from each replication were composited and a $100-\mathrm{g}$ subsample per replication was ground through a $40-$ mesh screen in a Wiley mill. The ground samples were used to determine crude protein, gross energy and in vitro dry matter digestibility.

Five fecal collections were made for each 30-day sampling period in each pasture type replication. During each fecal collection, feces were collected on every replication from observed defecating elk, immediately after defecation. Fecal collections were dried at $50^{\circ} \mathrm{C}\left( \pm 5^{\circ} \mathrm{C}\right)$, composited, and 100-g subsamples for each replication were ground through a 40 -mesh screen in a Wiley mill and analyzed for fecal crude protein (FP) and fecal gross energy (FE).

Crude protein (CP) was determined by the micro-Kjeldahl technique, and gross energy (GE) was determined by adiabatic bomb calorimetry. Dry matter digestibility (DMD) of the forage was determined by the two-stage in vitro method described by Tilley and Terry (1963) as modified by Vavra et al. (1973). Rumen inoculum was obtained from a fistulated steer that was fed hay, harvested from the experimental pasture, for 14 days prior to collecting inoculum. The literature indicated that the ability of rumen inoculum to digest feeds among different ruminants (elk, deer, and cattle) does not differ markedly, especially for those ruminants fed similar diets (McBee et al. 1969; Palmer et al. 1976; Robbins et al. 1975; Ward 1971). Thus cattle, rather than elk rumen fluid, was used in the in vitro digestion trials.

Estimates of digestible protein (DP) and digestible energy (DE) were calculated from equations in Crampton and Harris (1969).

Ten total counts of elk on the Beneke Creek W.M.A. were conducted during each monthly sampling period. Average Roosevelt elk weights were acquired from Hines (1972), Hines and Lemos (1975), and Lemos and Hines (1974).

The number of calves was converted to the number of adult equivalents by the following relationship:

$\frac{\text { Average calf weight } \mathrm{kg}^{0.75}}{\text { Average cow weight } \mathrm{kg}^{0.75}}=\frac{79 \mathrm{~kg}^{0.75}}{250 \mathrm{~kg}^{0.75}}=0.42$

(0.42) (number of calves) $=$ Adult elk equivalents for calves

(Adult elk

equivalents for calves $)+($ Adult elk $)=$ elk equivalents
The distribution of elk among plant communities and replications was measured by placing a $1 \times 100-\mathrm{m}$ plot in each plant community of each replication and counting pellet groups in each plot monthly. The number of pellet groups that had obviously deteriorated to the degree that they would not be present during the next count were recorded, and the next count was adjusted to provide an estimate of total pellets deposited per $100 \mathrm{~m}^{2}$ during each sampling period. The following relationship was used to estimate the density of adult elk equivalents (Elk) for each plant community (Comm.):

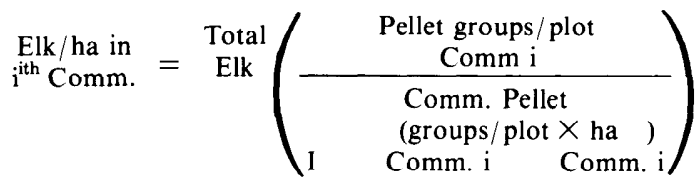

Estimates of Elk/ha/replication were used to apportion the amount of intake by Elk.

Data from standing biomass of herbage, herbage removal, elk density, gross energy, crude protein, and dry matter digestibility were pooled over years and tested for differences among pasture types and months using a split plot analysis of variance. Duncan's new multiple range test was used to test for significance of differences among treatment means where the analysis of variance indicated such differences existed. Throughout this paper the term significant refers to $P<.05$.

\section{Results}

\section{Standing Biomass of Herbage}

Standing biomass was affected by several inseparable factors, other than pasture types and weather. These factors were: grazing that occurred before the beginning of the study period in each winter, growth of herbage, and deterioration of hcrbage.

In December and January, the Bentgrass-U pasture type had the significantly greatest standing biomass with more than 4,000 $\mathrm{kg} / \mathrm{ha}$, while the Ryegrass-T pastures were lowest with about 2,000 $\mathrm{kg} /$ ha (Table 2). In February there was no significant difference found between the Bentgrass- $U$ and Bentgrass-T pastures, both of which had more than $3,000 \mathrm{~kg} / \mathrm{ha}$; however, they both had significantly more standing biomass than the Ryegrass- $T$ pasture type, which had about $1,700 \mathrm{~kg} / \mathrm{ha}$.

\section{Herbage Removal}

Monthly herbage removal in the Ryegrass-T pasture type varied from 640 to $770 \mathrm{~kg} / \mathrm{ha}$ and was significantly higher than in both the Bentgrass- $U$ and Bentgrass- $T$ pasture types, except in January, where it was not significantly different from the Bentgrass-T pasture type (Table 2). Based on personal observation and those of Wheeler (1976), elk use was determined to be the cause of nearly all

Table 2. Standing biomass of herbage and herbage removal for three pasture types on the Beneke Creek Wildlife Management Area for the winters of 1976-77 and 1977-78.

\begin{tabular}{lccc}
\hline & \multicolumn{3}{c}{ Pasture type } \\
\cline { 2 - 4 } Month & Bentgrass-U & Bentgrass-T & Ryegrass-T \\
\hline Standing biomass (kg/ha) & & & \\
$\quad$ December & $4113^{\mathrm{a} 1}$ & $3347^{\mathrm{b}}$ & $2397^{\mathrm{c}}$ \\
January & $4187^{\mathrm{a}}$ & $3623^{\mathrm{b}}$ & $1936^{\mathrm{c}}$ \\
February & $3520^{\mathrm{a}}$ & $3103^{\mathrm{a}}$ & $1719^{\mathrm{b}}$ \\
Herbage removal (kg/ha) & & & \\
December & $0^{\mathrm{a}}$ & $267^{\mathrm{a}}$ & $708^{\mathrm{b}}$ \\
January & $176^{\mathrm{a}}$ & $473^{\mathrm{ab}}$ & $779^{\mathrm{b}}$ \\
February & $78^{\mathrm{a}}$ & $0^{\mathrm{a}}$ & $646^{\mathrm{b}}$ \\
\hline
\end{tabular}

'Values within rows followed by the different letters were significantly different at P<.05. 
of the herbage removal on the Beneke Creek W.M.A. during the winter.

Significantly more herbage was removed in January than February from the Bentgrass-T pasture type. No other significant differences occurred between months within pasture types.

The lack of significant differences among herbage removal values that differ considerably numerically, as shown in Table 2, reflected the high variability of these data. Thus, individual observations were not reliable as estimates of elk intake. However, when the sum of herbage removed from the Beneke Creek W.M.A. from the total of 810 paired plots was divided by a pooled estimate of elk density, the average intake per adult elk equivalent per month was $173 \mathrm{~kg}$ (22.93 g forage consumed daily/ $\mathrm{kg}$ body weight). This was within the range of results of others for free ranging adult ruminants (Table 3 ).

Table 3. Comparison of elk intake during the winter determined from herbage removal data to estimates by other authors.

\begin{tabular}{lcl}
\hline \hline & Intake $^{1}$ & Type of animal \\
\hline $\begin{array}{l}\text { Determined from herbage } \\
\quad \text { removal data }\end{array}$ & 22.9 & Roosevelt elk \\
Thorne et al. 1976 & 22.8 & Rocky Mountain elk \\
Thorne and Butler 1976 & 24.2 & Rocky Mountain elk \\
Ralcigh and Lesperance & & \\
$\quad 1972$ & 21.3 & Cattle \\
Alldredge et al. 1974 & 20.1 & Mule deer \\
\hline
\end{tabular}

IIntake is expressed as $\mathrm{g}$ forage consumed daily/ $\mathrm{kg}$ body weight.

\section{Elk Density and Distribution}

An average of 168 elk used the Beneke Creek W.M.A. during the winter study periods of 1976-77 and 1977-78. The average elk density on the 78 ha of pasture was 2.15 elk/ ha of pasture.

No significant differences were found for the effects of months on elk density. There were no significant differences in elk density between the Bentgrass- $U$ and Bentgrass- $T$ pasture types at 0.4 and $1.3 \mathrm{elk} /$ ha, respectively, but elk density on the Ryegrass-T pasture type was significantly higher than on the other pasture types with 4.4 elk/ha.

\section{Digestible Energy}

Forage from the Ryegrass-T pasture type had 2.1 to $2.7 \mathrm{Mcal} / \mathrm{kg}$ of DE. This was significantly higher than forage from both the Bentgrass-U and Bentgrass-T pasture types with 1.3 to 1.7 $\mathrm{Mcal} / \mathrm{kg}$ DE, respectively (Table 4). Digestible energy concentration in forage from the Bentgrass- $U$ and Bentgrass- $T$ pasture types did not differ significantly. Digestible energy in forage from the Ryegrass-T pasture type was significantly higher in December than in February. No other significant differences occurred between months within pasture types.

Forage from the Ryegrass- $T$ pasture type consistently exceeded the minimum energy requirement of $1.83 \mathrm{Mcal} / \mathrm{kg}$ for free ranging cattle and sheep, as reported by Cook and Harris (1968). However, forage from the other two pastures was below the minimum requirement.

\section{Digestible Protein}

Forage from the Ryegrass-T pasture type showed the significantly highest concentration of digestible protein (DP), while forage from the Bentgrass-U pasture types had the lowest (Table 4). The average concentrations of DP in forage from the Ryegrass-T pasture types exceeded the minimum DP requirement of $4.4 \%$ suggested by Cook and Harris (1968) for range cattle and sheep during the winter. The DP averages in the Bentgrass- $U$ and Bentgrass-T pasture types were always below this level.

\section{Discussion}

In general the Bentgrass- $U$ pasture type had the most available
Table 4. Digestible energy and digestible protein for three pasture types on The Beneke Creek Wildlife Management Area for the winters of 1976-77 and 1977-78.

\begin{tabular}{lccc}
\hline & \multicolumn{3}{c}{ Pasture type } \\
\cline { 2 - 4 } Month & Bentgrass-U & Bentgrass-T & Ryegrass-T \\
\hline Digestible energy (Mcal/kg) & $1.5^{\mathrm{a}}$ & $1.7^{\mathrm{a}}$ & $2.7^{\mathrm{b}}$ \\
December & $1.5^{\mathrm{a}}$ & $1.7^{\mathrm{a}}$ & $2.2^{\mathrm{b}}$ \\
January & $1.3^{\mathrm{a}}$ & $1.7^{\mathrm{a}}$ & $2.1^{\mathrm{b}}$ \\
February & & & \\
Digestible protein (\%) & $0^{\mathrm{a}}$ & $3.0^{\mathrm{b}}$ & $9.2^{\mathrm{c}}$ \\
December & $0^{\mathrm{a}}$ & $2.0^{\mathrm{b}}$ & $7.7^{\mathrm{c}}$ \\
January & $0^{\mathrm{a}}$ & $2.0^{\mathrm{b}}$ & $10.9^{\mathrm{c}}$ \\
February &
\end{tabular}

IValues within rows followed by the different letters were significantly different at $P<.05$.

herbage and the Ryegrass- $T$ pasture type the least (Table 2). However, elk preferred to graze the Ryegrass-T pasture more than the Bentgrass-U and Bentgrass-T pasture types, which were similar to each other. Forage availability had a negative relationship to grazing preference and herbage removal. Feeds that were higher in nutritive value have been shown to be preferred over plants of lower nutritive quality (Cook 1965; Heady 1964; Voigt 1975). This secms to have been the case on the Beneke Creek W.M.A. The forage in the Ryegrass-T pasture type was higher in DE and DP than the other two pasture types. The Bentgrass-T pasture type was higher in DP and the same in DE as the Bentgrass-U pasture type. The differences in nutritive values between the Bentgrass- $U$ and Bentgrass-T pasture types either were not great enough to influence elk use or differences in the levels of elk use were too small to detect. Perhaps another factor in these two pastures influenced elk use more than nutritive value of forage.

Throughout winter, forage in the Ryegrass-T pasture type exceeded the recommended minimum concentrations of DP and DE by Cook and Harris (1968). However, deficiencies in DP were indicated in part of the winter of 1976-77 during a period of alternate freezing and thawing. The Bentgrass- $T$ pasture types's forage was marginal for DE and generally deficient in DP. The herbage in the Bentgrass- $U$ pasture type never reached minimum requirement levels for DE and DP. This does not mean that the diets of elk using the Bentgrass- $U$ and Bentgrass- $T$ pasture types were always deficient in energy and protein. Bedell (1971) stated that the diets of sheep and cattle on ryegrass-subterranean clover pastures contained higher concentrations of crude protein than was available in the herbage. This indicated that the sheep and cattle were selecting plants and parts of plants higher in crude protein over those with lower crude protein concentration. It was possible that, through selective grazing, elk diets were of a higher quality than the forage nutrient data indicated. However, the forage quality data indicated that elk had much more opportunity to acquire adequate levels of DP and DE in the Ryegrass-T pasture type than in either the Bentgrass- $U$ or Bentgrass-T pasture types. Additionally, elk had a better chance of consuming a nutritionally adequate diet in the Bentgrass-T pasture type than they did in the Bentgrass- $U$ pasture type.

Protein and energy in ruminant diets have been directly tied to survival and reproduction (Allden 1970; Verme 1965; Zimmerman et al. 1961; Holter and Hayes 1977; Thorne et al. 1976). Trainer (1971) reported that the inability of Roosevelt elk cows to maintain energy (fat) reserves was responsible for their relatively low rates of reproduction in Oregon. He suspected that inadequate nutrients in the forage may have been the cause of the relatively poor body conditions observed. The relatively low $\mathrm{DE}$ levels shown for forage from the Bentgrass- $U$ and Bentgrass- $T$ pasture types (Table 4) indicated that Trainer's (1971) suspicions were well founded, since most Roosevelt elk winter habitat was similar in characteristics to the Bentgrass- $U$ and Bentgrass- $T$ pasture types, except that very little was ever fertilized as the Bentgrass-T pasture type was. The 
higher and nutritionally adequate levels of DE and DP in the Ryegrass-T pasture type suggested that Roosevelt elk with access to these types of pasture should be able to maintain higher rates of reproduction and survival of offspring than is generally noted across their range in Oregon.

\section{Literature Cited}

Allden, W.B. 1970. The effects of nutritional deprivation on the subsequent productivity of sheep and cattle. Nutr. Abstr. Rev. 40:1167-1184.

Alldredge, W.A., J.F. Lipscombe, and F.W. Whicker. 1974. Forage intake rates of mule deer estimated with fallout Cesium-137. J. Wildl. Manage. 38:508-516.

Beaulieu. J.D. 1973. Environmental geology of inland Tillamook and Clatsop counties, Oregon. Dep. of Geology and Mineral Industries, State of Oregon Bull. 79. $65 \mathrm{p}$.

Bedell, T.E. 1971. Nutritive value of forage and diets of sheep and cattle from Oregon subclover-grass mixtures. J. Range Manage. 24:125-133.

Cook, C.W. 1965. Plant and livestock responses to fertilized rangelands. Utah Agr. Exp. Sta. Bull. 455. 35 p.

Cook, C.W., and L.E. Harris. 1968. Nutritive value of seasonal ranges. Utah Agr. Exp. Sta. Bull. 472.55 p.

Crampton, E.W., and L.E. Harris. 1969. Applied Animal Nutrition. W.H. Freeman and Co., San Francisco. 753 p.

Harper, J.A. 1962. Daytime feeding habits of Roosevelt elk on Boyes Prairie, California. J. Wildl. Manage. 26:97-100.

Heady, H.F. 1964. Palatability of herbage and animal preference. J. Range Manage. 17:76-82.

Hines, W.W. 1972. Ecological study of Roosevelt elk; elk investigations. Oregon State Game Commission. W-70-R-2, Subproj. C. 22 p.

Hines, W.W., and J.C. Lemos. 1975. Ecological study of Roosevelet elk; elk investigations. Oregon Wildl. Commission. W-70-R-5, Subproj. C. 18 p.

Holter, J.B., and H.H. Hayes. 1977. Growth in white-tailed deer fawns fed varying energy and constant protein. J. Wildl. Manage. 41:506-510.

Lemos, J.C., and W.W. Hines. 1974. Ecological study of Roosevelet elk; Enclosure Study. Oregon Wildl. Commission. W-70-R-4, Subproj. C. 40 p.

McBee, R.H., J.L. Johnson, and M.P. Bryant. 1969. Ruminal microorganisms from elk. J. Wildl. Manage. 33:181-186.
NOAA. 1966-1978. Climatological data. National Oceanic and Atmospheric Administration, Dep. of Commercc. U.S.A. Vol. 72-84.

Palmer, W.L., R.L. Cowan, and A.P. Ammann. 1976. Effects of inoculum source on the in vitro digestion of deer foods. J. Wildl. Manage. 40:301307

Raleigh, R.J., and A.L. Lesperance. 1972. Range cattle nutrition. p. 185199d. In: D.C. Church (Ed.). Digestive Physiology and Nutrition of Ruminants; Vol. 3 - Practical nutrition. D.C. Church, Corvallis, Oregon. $351 \mathrm{p}$.

Robbins, C.T., P.J. VanSoest, W.W. Mautz, and A.N. Moen. 1975. Feed analyses and digestion with reference to white-tailed deer. J. Wildl. Manage. 39:67-69.

Schwartz, J.E., and G.E. Mitchell. 1945. The Roosevelt elk on the Olympic Peninsula, Washington. J. Wildl. Manage. 9:295-319.

Thorne, T., and G. Butler. 1976. Comparison of pelleted, cubed and baled alfalfa hay as winter feed for elk. Wildl. Tech. Rep. No. 6. Wyoming Game and Fish Dep. 38 p.

Thorne, E.T., R.E. Dean, and W.G. Hepworth. 1976. Nutrition during gestation in relation to successful reproduction in elk. J. Wildl. Manage. 40:330-335.

Tilley, J.M.A., and R.A. Terry. 1963. A two stage technique for the in vitro digestion of forage crops. Brit. Grassland Soc. J. 18:104-111.

Trainer, C.E. 1971. The relationship of physical condition and fertility of female Roosevclt elk (Cervus canadensis roosevelti). M.S. Thcsis. Oregon State Univ., Corvallis. 95 p.

Vavra, M., R.W. Rice, and R.E. Bement. 1973. Chemical composition of the diet, intake and gain of yearling cattle on different grazing intensities. J. Anim. Sci. 36:411-414.

Verme, L.J. 1965. Reproduction studies on penned white-tailed deer. J. Wildl. Manage. 29:74-79.

Voigt, P.W. 1975. Improving palatability of range plants. p. 23-49. In: Campbell, R.S., C.H. Herbel. Improved Range Plants. Soc. for Range Manage., Denver, Colo. Range Symp. Series No. 1. 90 p.

Ward, A.L. 1971. In vitro digestibility of elk winter forage in southern Wyoming. J. Wildl. Manage. 35:681-688.

Wheeler, D. 1976. Personal communication. Area Manager Jewell Wildlife Meadows, Oregon Dep. of Fish and Wildl., Jewell, Oregon.

Zimmerman, D.R., D.C. Clanton and J.K. Matsushina. 1961. Postpartum reproductive performance in beef heifers as affected by protein and energy intake during gestation. J. Anim. Sci. 20:957.

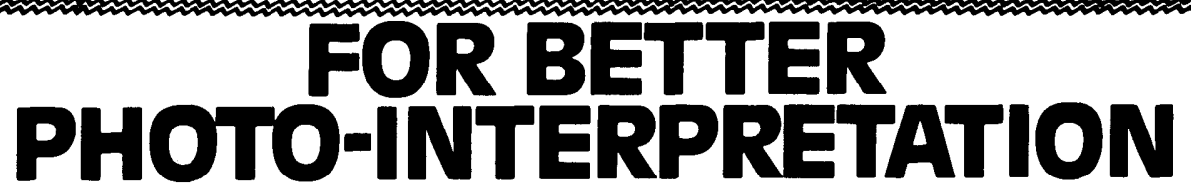

\begin{abstract}
- A stereoscopic view • High resolution
- Continuously variable, in-focus magnification With the Bausch \& Lomb SIS-95 Stereo

Interpretation System you see everything there is to see in high altitude photographs-and you see it in three dimensions. The SIS-95 zoom optical system-continuously variable in-focus magnification-enables you to select the exact magnification you need for fast, easy interpretation.

The SIS-95 includes a Bausch \& Lomb Zoom 95
\end{abstract}

\section{Stereoscope}

mounted on a specially designed light table. With simplified scalematching, you quickly adjust for stereo viewing of photographic transparencies or prints. The SIS-95 gives you all

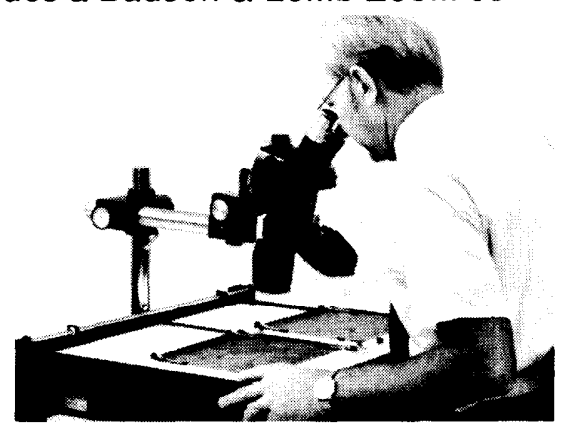

this at about half the price of its nearest competitor. A companion instrument, the Bausch \& Lomb ZOOM TRANSFER SCOPE ${ }^{\text {TM }}$ instrument, will greatly aid you in graphical data transfer work, including map completion, map revision and the preparation of special purpose maps.

We'll be glad to discuss the application of the SIS-95 or ZOOM TRANSFER SCOPE ${ }^{T M}$ instrument in meeting your needs. Call us at (716) 338-6000. Or send coupon for illustrated brochures.

Mail to:
Bausch \& Lomb
Scientific Optical Products Division
Attn: Dept. 6606 York 14602 USA
Rochester, New York
Please send your SIS-95 brochure.
Please send your Z.T.S. brochure.
Address
Telephone

\section{BAUSCHa LOMB}

Scientific Optical Products Division

Rochester, New York 14602 USA, 716-338-6000, TWX 510-253-6189, TELEX 97-8231, CABLE: BAUSCH \& LOMB

In CANADA: Bausch \& Lomb Canada Ltd., 2001 Leslie Street, Don Mills, M3B2M3, Ontario, Canada, (416) 447-9101 